\title{
From marginality to further marginalization: Experiences from the victims of the July 2000 Payatas trashslide in the Philippines
}

JC Gaillard

UMR 5194 Pacte - CNRS, Université de Grenoble, France Department of Geography, University of the Philippines Diliman Jean-Christophe.gaillard@ujf-grenoble.fr

Jake Rom D. Cadag

EA 3766 Gester, Université Paul Valery - Montpellier III, France Department of Geography, University of the Philippines Diliman

jrdcadag@yahoo.com

Oh honey when I die

Dress me up in a coat and tie

Give my feet a pair of shoes

That I haven't wore in a long time

Put me in a golden box

Not a cross on a pile of rocks

Bury me where the grass is green

And the gates are shining

- Ely Buendia, Eraserheads, Poorman's grave, 1995

\section{ABSTRACT}

Victims of disasters are disproportionately drawn from the marginalized segments of society. Disaster victims are marginalized geographically because they live in hazardous places, socially because they are members of minority groups, economically because they are poor, and marginalized politically because their voice is disregarded by those with political power. The victims of the July 2000 Payatas trash slide in the Philippines show all these characteristics. Most of the victims of the disaster were urban migrants who came all the way from their poor provinces to settle on the lower slopes of the largest dumpsite of the country. They scavenged recyclable materials to sell as a way to make a living, but their limited incomes did not allow them to afford safer locations for their homes, farther removed from the slopes of the dumpsite. On the morning of 10 July 2000, 300 of them lost their lives when a large section of the dumpsite collapsed in a massive debris flow which buried their houses. In the aftermath of the disaster, 
From marginality to further marginalization: Experiences from the victims of the July 2000 Payatas...

the survivors who used to live on the dumpsite, and who were the poorest victims, were also those who were relocated by the Philippine government. In the present case, the most vulnerable families in the face of the trash slide were eventually those who had to suffer again from life-disrupting relocation while being the less able to recover quickly from the disaster. Daily incomes of relocated families are today much lower than those who remained in the vicinity of the dumpsite. For the victims of the July 2000 Payatas tragedy, poverty thus acted as a vicious, worsening circle which ranged from vulnerability to poor recovery, or from marginality to further marginalization.

\section{KEYWORDS}

Disaster, Marginality, Vulnerability, Recovery, Livelihood, Payatas, Philippines.

\section{Introduction}

Victims of disasters are disproportionately drawn from the marginalized segments of society. Most victims of disasters are marginalized geographically because they live in hazardous places, socially because they are members of minority groups, economically because they are poor, and marginalized politically because their voice is disregarded by those with political power (e.g. Blaikie \& Brookfield, 1986; Wisner, 1993; Wisner et al., 2004). Marginalization usually leads to high vulnerability in facing natural hazards. Vulnerability refers to the propensity to suffer from damage should natural phenomena occur or, in other terms, the condition of a society which makes it possible for a hazard to become a disaster (Cannon, 1994).

Marginalization does not stop with the occurrence of disasters as disastrous events do not equalise victims in suffering. People who were rich before will still be the most well-off after the event while the poor are likely to remain poor (Quarantelli \& Dynes, 1972; Blaikie et al., 1994). This of course relates to pre-disaster vulnerability and the extent of resources left to recover. It also pertains to post-disaster aid and relief which is often unfairly distributed to the benefit of the most affluent segments of society (Cuny, 1983; Middleton \& O’Keefe, 1998). Therefore, disasters frequently lead to more marginalized people as the victims who have lost their livelihoods are often unable to recover (Walker, 1989; Wisner, 1993; Winchester, 1992).

This process of marginalization, from pre-disaster vulnerability to post-disaster recovery, has been formalized by Susman et al. (1983) and Wisner (1993) (Figure 1). Both references emphasize that increasing marginalization heightens people's vulnerability in the face of natural hazards through underdevelopment and environmental degradation. Disasters are thus more frequent. Eventually relief aid reinforces the status quo and leads to further marginalization and underdevelopment which pave the way for more disasters to happen. There are a significant number of references available on the process of marginalization which leads to people's vulnerability in facing natural hazards (e.g. Wisner, 1993; Wisner et al., 2004). Another important set of research works address post-disaster relief aid and assistance with the objective of showing how unfair it often is (e.g. Cuny, 1983; Middleton \& O'Keefe, 1998). Yet fewer studies address the links between pre- and post-disaster marginalization or how people's vulnerability affects their ability to recover in the aftermath of a disaster. 


\section{Fig 1. Process of marginalization of disaster victims}

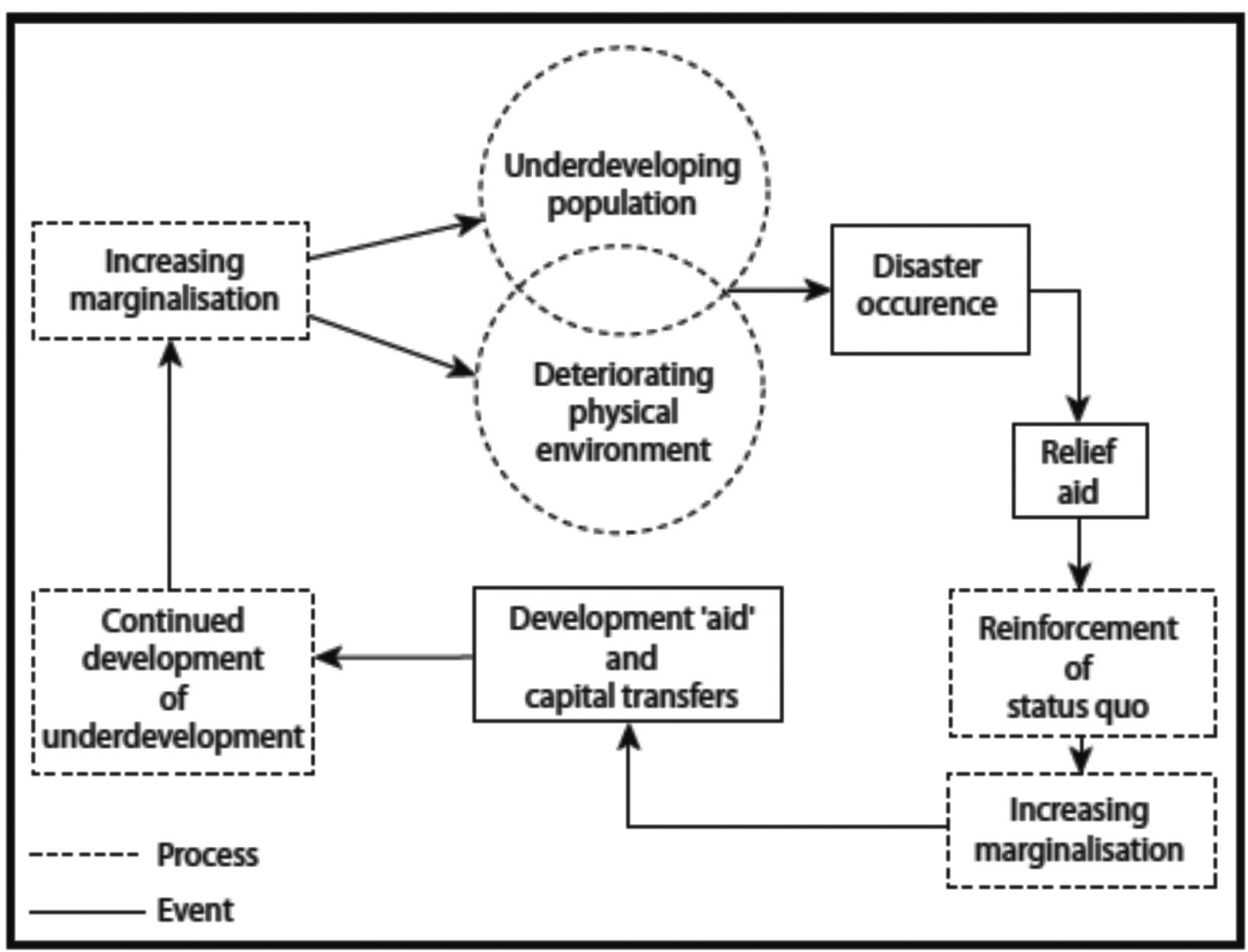

Source: Susman et al., 1983

The present study is an attempt to fill this gap based on the results of a study conducted among the victims of the July 2000 Payatas trashslide in the Philippines. It particularly focuses on people's livelihoods as an indicator of marginalization, vulnerability and poor recovery. It is noteworthy that this study does not investigate the root causes of people's marginalization and vulnerability in the face of the trashslide hazard. It does, however, address the links between pre- and post-disaster marginalization or how the victims have been able to recover (or not) from the perspective of their initial vulnerability. This research encompasses both the people who chose to remain near their former home and those who accepted relocation in the Kasiglahan resettlement site. Section I will link people's livelihood and marginalization based on a short review of the existing literature. Section II will provide a glimpse on the July 2000 Payatas tragedy. Section III will describe the methodology used for the study. Section IV and V will respectively focus on how the victims who chose to remain in Payatas and those who relocated to Kasiglahan recovered from the disaster. Section VI and VII will finally tie up marginalization, pre-disaster vulnerability and post-disaster recovery in the context of sustainable livelihoods.

\section{Marginality and people's livelihood}

Marginality and livelihoods are closely related concepts as marginality reflects poor entitlement to livelihoods. The concept of livelihood emerged in the 1980s as an alternative to the techno- 
cratic concept of 'employment' to better describe how people struggle to make a living. It emphasizes people's views of their own needs. Chambers and Conway (1991:1) define sustainable livelihoods as follows: 'A livelihood comprises people, their capabilities and their means of living, including food, income and assets. Tangible assets are resources and stores, and intangible assets are claims and access. A livelihood is environmentally sustainable when it maintains and enhances the local and global assets on which livelihoods depend, and has net beneficial effects on other livelihoods. A livelihood is socially sustainable which can cope with and recover from stress and shocks, and provide for future generations'. Livelihoods thus refer to the means and capacities required to sustain durably people's basic needs. Basic needs are vitally linked to food, but also include shelter, clothing, cultural values and social relationships.

The capacity to meet food and other basic needs depends on assets and capital. The Department of International Development (1999) distinguishes five types of capital: natural capital (land, water, forest, air and other natural resources), human capital (health, skills and knowledge), social capital (kinship, social networks, and associations), financial capital (cash, savings, credit, jewellery and other valuables) and physical capital (housing, infrastructure, work implements, livestock and domestic utensils). Wisner (2009) further identifies an institutional capital which includes the interface with formal governance and government-linked services, information and assets. In the present paper, we will refer to this form of resources as political capital in order to encompass the larger access to the political scene. The extent, strength and diversity of the various forms of capital condition people's capacity to produce their own food. These factors also command the capacity to purchase food should it not be supplied by the household itself. In the latter case, the availability of food depends on the larger political economy framework (Start \& Johnson, 2004). The availability and extent of capital or assets is indeed deeply dependent on claims and access. Claims refer to rights and capacities/power to ask for some external support to sustain basic needs should people be unable to meet them by themselves. Claims thus depend on the extent of people's social, economic and political networks and relationships. This is complemented by access which is the opportunity to use available stores and resources or obtain food, employment, technology and information (Chambers \& Conway, 1991). As underlined by Sen (1981a; 1981b), people's claims for and access to livelihoods thus go beyond the specific availability or unavailability of livelihoods but encompass the capability or entitlement to use available resources. Watts and Bohle (1993) emphasize that entitlement to livelihoods reflects people's empowerment evident in class relationships and the larger distribution of economic wealth, social opportunities and political power within the society.

Entitlement and empowerment to access the different forms of capital which compose livelihoods reflect people's position within the society and the different forms of marginalization disaster victims suffer from. Geographical marginality which leads people to settle in hazardprone areas reflects poor access to natural capital. The inability to access safe lands and other natural resources forces people to live in hazard-prone areas to sustain their daily needs. Economic marginality or the lack of financial and physical capital further prevents people from accessing the means of protection (resistant housing, warning systems, evacuation routes, safe shelter, etc) should they be compelled to live in hazardous areas due to insufficient natural 
capital. This inability to protect oneself in the face of natural hazards also mirrors social marginality as it may result from poor access to human capital (fragile health status, little knowledge of hazards and protection means) which leads to increased vulnerability. Geographical, social and economic marginality is ultimately tied to limited social capital and powerlessness, i.e. political marginality and the lack of political capital, as it prevents access to other forms of capital. A startling example is provided by Kent (1988:193) in the context of malnutrition: "Malnutrition is due to poverty, but even more fundamentally to powerlessness. Poverty may put the family unit at risk of malnutrition, but it does not explain the discrepancies in nutritional status within the family".

\section{The July 2000 Payatas tragedy}

The 20-heactare Payatas dumpsite is located in the municipality of Quezon City, north of the capital region of Metro Manila in the Philippines (Figure 2).

\section{Fig 2. Location of the Payatas dumpsite}

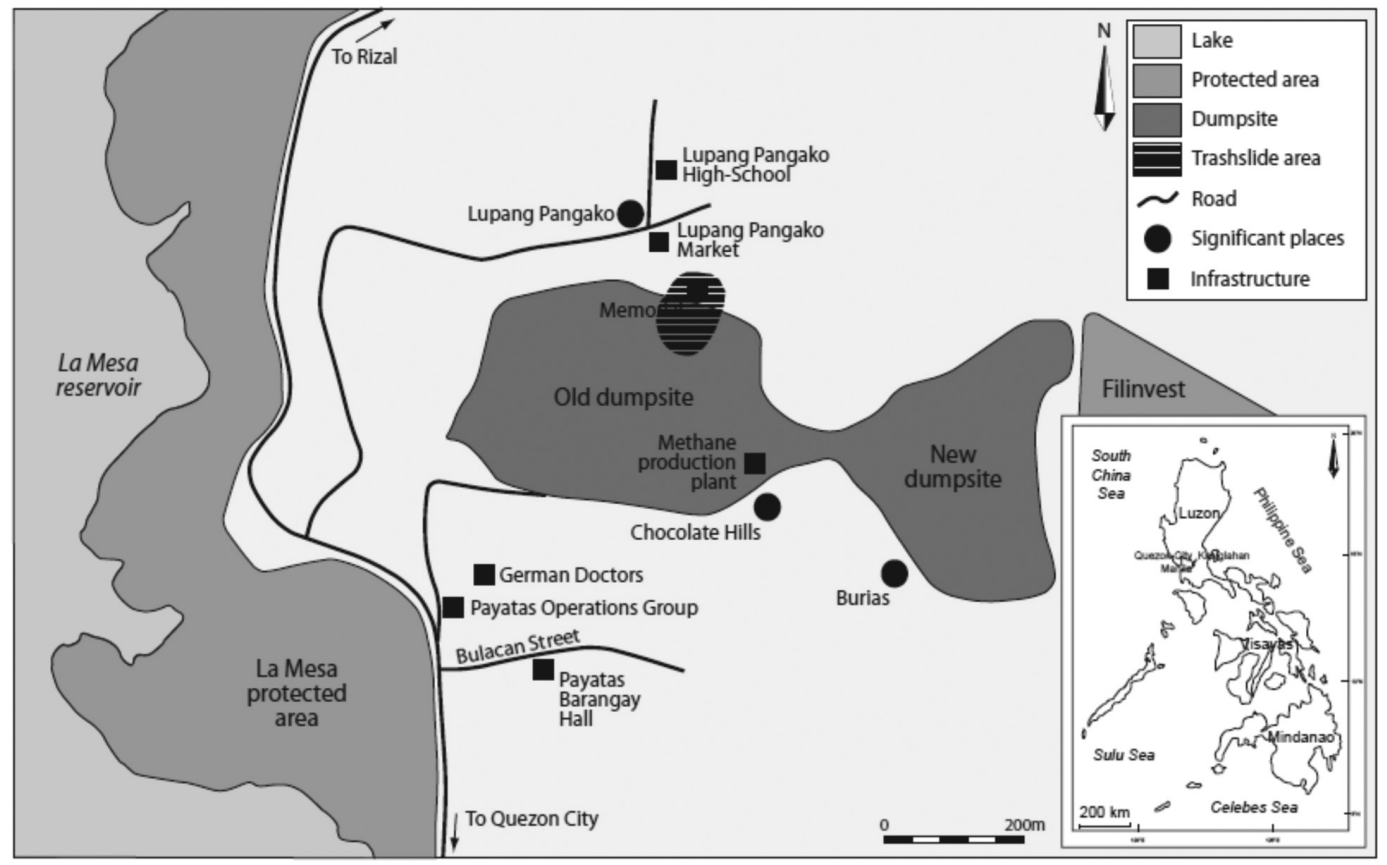

Source: Gaillard et al., 2008

Early on the morning of 10 July 2000 a huge section of the dumpsite collapsed into a massive debris flow. Official figures report that 330 people were entombed alive and died in the area called Lupang Pangako or the "Promised Land". Hundreds of houses were totally buried under metres of garbage or burned by subsequent fires. Seeping leachate further flooded the surrounding dwellings (Figure 3). Geotechnical engineers reported that the landfill failure had been triggered by extremely heavy rainfall caused by two successive typhoons (Merry et al., 2005). Noteworthy is that the 2000 trashslide was not the first to hit the area. On 3 August 1999 a similar event buried several houses of Lupang Pangako, but fortunately nobody was killed. 


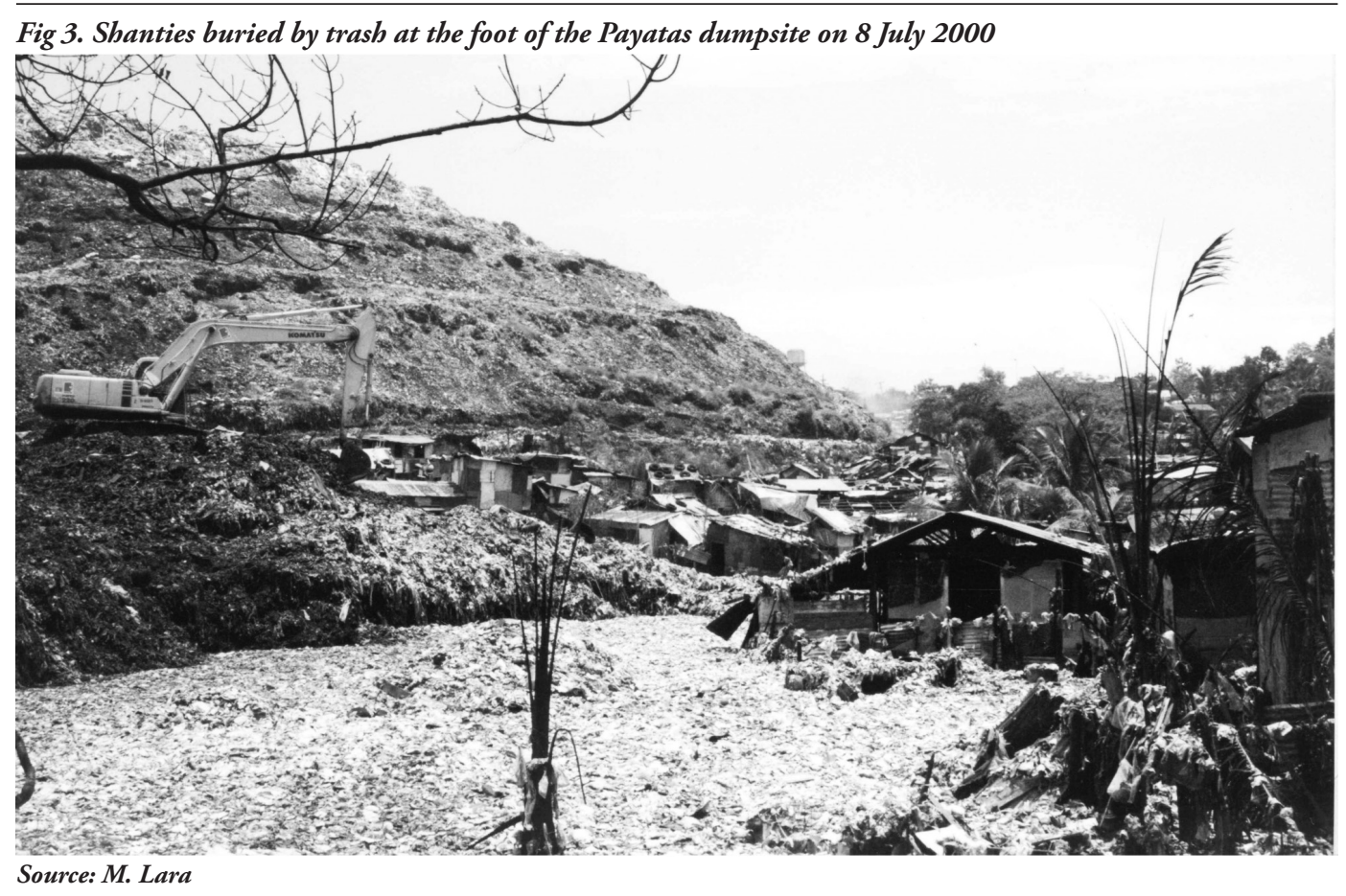

Most of the victims of the July 2000 tragedy were economically marginalized, indigent people, with poor financial and human capital, who made a living from scavenging into, sorting and selling the garbage (Table 1). They were geographically marginalized as they used to live at the bottom or on the lower slopes of the dumpsite in makeshift houses made of scrap materials

Table 1. Daily incomes of households affected by the July 2000 trashslide in Payatas

\begin{tabular}{|c|c|}
\hline Daily incomes (in Php) & Number of households \\
\hline Less than 100 & 97 \\
\hline 100 to 199 & 285 \\
\hline 200 to 299 & 119 \\
\hline 300 to 399 & 22 \\
\hline 400 to 499 & 0 \\
\hline 500 and more & 5 \\
\hline No data & 89 \\
\hline
\end{tabular}

Source: Data from Quezon City Social Services Development Department - Note: $45 \mathrm{php}=\sim 1$ US\$

reflecting limited physical capital. Lupang Pangako actually grew in the late 1980s as a resettlement site for squatters evicted from other areas of Quezon City. In 1994 the Metro Manila Development Authority (MMDA) transformed the small local dumpsite into the biggest dumpsite planned for receiving garbage from the entire capital region. The fast growth of the 
dumpsite progressively attracted thousands of poor families looking for livelihoods (Bernardo, 2004). Official figures show that the population of the Payatas administrative unit grew by 60\% between 1994 and 2000 to reach 112,690 inhabitants (National Statistics Office, 2009). However, local officials and researchers estimated that 30 to $80 \%$ of the actual population could have been illegal settlers who were not covered by the 2000 census (Pecson, 2000; Bernardo, 2004). They were politically and socially marginalized and thus lacked access to land (natural capital) and social and political capital.

The scope of the disaster thus mirrors people's vulnerability, poor livelihoods and marginality at the start of the event. Families whose houses were buried under several metres of garbage were illegal settlers living in very poor conditions in the immediate vicinity of the dumpsite. They reflect the uttermost level of geographical, economic, social and political marginality. On the other hand, most households who were only flooded by seeping leachate were legal beneficiaries of the 1980s' resettlement programme who were less marginalized and lived in better off conditions. The process of marginalization which led people to be highly vulnerable in the face of the trashslide hazard is a classic story of urban poverty where first-generation migrants are compelled to live in hazard-prone areas to sustain their daily needs, yet lacking adequate access to protection means. The root causes of such a process have been thoroughly addressed in the literature (e.g. Davis, 1987; Wisner et al., 2004).

Immediately after the disaster, 626 affected families living in the immediate surroundings of the landfill were evacuated to public buildings (schools and gymnasiums). The Department of Social Welfare and Development (DSWD) along with some local and foreign NGOs provided first aid and support to the victims in the form of medical assistance, food, clothes and other everyday utensils. Most of the victims stayed for several weeks within the evacuation centres. Eventually, 58 families accepted to go back to their native province with the financial support of the DSWD. Altogether 147 other households resettled in the houses of relatives in the vicinity.

Facing the incapacity to send the other victims back to the landfill, the municipal government of Quezon City entered into negotiations with the National Housing Authority (NHA) for the relocation of the affected families. The Kasiglahan (literally "Liveliness") resettlement site in the municipalities of Rodriguez (Montalban) in the province of Rizal, was considered as a favourable alternative given its relative proximity to Payatas. Originally, Kasiglahan was developed as a resettlement site for thousands of illegal settlers from the banks of the Pasig River which drains, among others, the municipality of Manila. Within a month of the disaster, the first victims of the Payatas tragedy began to move to their new home in Kasiglahan. Three kinds of households were eligible for resettlement: $1 /$ families who had lost some relatives in the disaster; 2/ families whose houses had been buried by the transhslide and 3/ families who were living within a newly defined danger zone. Overall, 571 families from Lupang Pangako received a piece of land of 32 to $40-\mathrm{m}^{2}$ and a $20-\mathrm{m}^{2}$ concrete house equipped with sanitary facilities. Planners acknowledge that the houses were designed to optimize the available funding. Yet resettlers have to pay back US\$ 4,120 over 30 years (plus 6\% in yearly interest) for 
receiving the legal title to their new house and lot. As of late 2007, only 108 families had begun to pay. In parallel, a number of microfinance and livelihood projects were designed by the DSWD to provide the victims with new jobs near Kasiglahan.

Driven by the lack of livelihoods, an indefinite number of the resettlers of Kasiglahan progressively chose to move back to their original place in Lupang Pangako. They were joined by some new migrants who came to Payatas in search of economic alternatives to their poor way of life in remote provinces of the archipelago and other areas of Metro Manila (Bernardo, 2004). Interviews show that most of these newcomers settled at the foot of the new dumpsite on private or governmental lands in exchange of paying small rights to the owner or initial dweller.

\section{Methodology}

The forthcoming discussion relies first on an extensive series of interviews with key informants conducted between August 2007 and July 2009, or between seven and nine years after the disaster. A number of victims and leaders of associations of victims were interviewed in both the Kasiglahan resettlement site and Lupang Pangako and neighbouring quarters. These interviews provided an initial overview of how people coped with the disaster and its aftermath. In parallel, interviews were conducted with representatives of the local government, DSWD, MMDA, the Department of Environment and Natural Resources, NHA, the Payatas Operations Group (POG), local health services, NGOs, associations of scavengers and junkshop owners and workers. These interviews were aimed at assessing the role of the authorities and other stakeholders in the management of the crisis and rehabilitation following the disaster. A large number of useful primary written documents were also collected during visits to these organizations.

Secondly, a questionnaire-based survey was carried out in Lupang Pangako and Kasiglahan to validate hypotheses drawn from the interviews with key informants, i.e. that the strength, diversity and sustainability of livelihoods were crucial to the ability of victims to recover from the disaster. Given the lack of reliable census data and other population counts in Payatas, it was impracticable to rationally use any statistical sampling method. On the other hand, a credible geography-based sample relying on aerial photographs or satellite images was impossible given the slum-type nature of settlements in Payatas. Therefore, 30 (the usually accepted statistical validity threshold) face-to-face in-depth interviews were conducted at each site using a 58-item questionnaire in December 2007. The questionnaire was designed with the objective of assessing victims' recovery based on their livelihoods before and after the disaster. It included an initial series of questions concerning personal experience of the tragedy. In a second series of questions, changes in people's daily lives following the disaster were addressed. The third part of the questionnaire was an overall assessment of the post-disaster situation and the future by the victims. A fourth section on general demographics concluded the questionnaire. In Kasiglahan, an additional set of questions addressed the resettlement process. Interviews were conducted in Tagalog. The selection of interviewees reflected the actual distribution of the population in terms of age and sex. The limited size of the sample means that the statistical power of inferential tests and other forms of modelling was reduced. The analysis, therefore, relies exclusively on descriptive statistics. 
Fieldwork was completed with the collection of secondary written documents such as journal publications, conference proceedings, and relevant press clippings from local and national newspapers. It is particularly noteworthy that a large part of this set of data was initially exploited in a study using the concept of resilience as conceptual framework (Gaillard et al., 2008; Le Masson, 2008).

\section{Rising out of the trashes: How to survive in Payatas?}

Following the July 2000 tragedy, then President Joseph Estrada decided to close the Payatas dumpsite. The lack of a viable alternative to accommodate the garbage of Metro Manila forced the authorities to eventually reopen it four months later. It was then decided to convert the simple dumpsite into a controlled dumpsite placed under the authority of the POG. The new facilities include a circumferential fence and a permanent danger zone where any construction is prohibited. At the same time scavengers were organized into associations which are in charge of managing working shifts for accessing the dumpsite. The surroundings of the dumpsite also became the focus of many development projects initiated by the government and local or international NGOs. This evolution in the management of the dumpsite and the influx of development programmes brought some changes in the way of life of the victims of the July 2000 tragedy.

The families who were not relocated to Kasiglahan were those who were living outside of the danger zone and whose houses had not been damaged by the trashslide. Seven years after the disaster, these households managed to upgrade their houses. Before the tragedy, $93 \%$ of the interviewees lived in makeshift houses made of scrap materials. Today, $73 \%$ of them occupy houses which are partially cemented. Yet some of them are still struggling to obtain a title for the piece of land on which their house is built. Despite some initiatives from the local government to help squatters securing legal properties, access to land is still a major issue in Payatas. In fact, in-migrations have not stopped in the aftermath of the disaster. Thousands of new migrants coming from poor provinces of the archipelago have settled within the danger zone over which the government is unable to exert strong control. A female interviewee summarizes the situation as follows: 'we are aware of the danger of a possible trashslide but hunger forces us to settle here to secure enough income to sustain our daily needs without paying expensive rents'.

The POG's policy to control access to the dumpsite and impose shifts among scavengers led to a significant reduction in scavengers' incomes. Before the disaster, most of them used to resort to metamphetamine to be able to work sometimes more than 12 hours a day on the dumpsite. They were further able to sell sorted garbage directly to junkshops which mushroomed in the surroundings. Today, they work eight hours a day and sell trash to middlemen on the dumpsite. To cope with this situation, most of the scavengers have had to diversify their livelihoods. Today only $10 \%$ of the victims interviewed as part of this study are full-time scavengers. Others became street vendors (33\%) or engaged in other informal jobs like construction worker, sweeper, janitor, etc. A significant proportion of the victims (10\%) are also jobless and rely on relatives or friends' support to sustain their daily needs. Most of the victims of the July 2000 tragedy who remained in Payatas have observed a decrease in their incomes (Figure 4). 


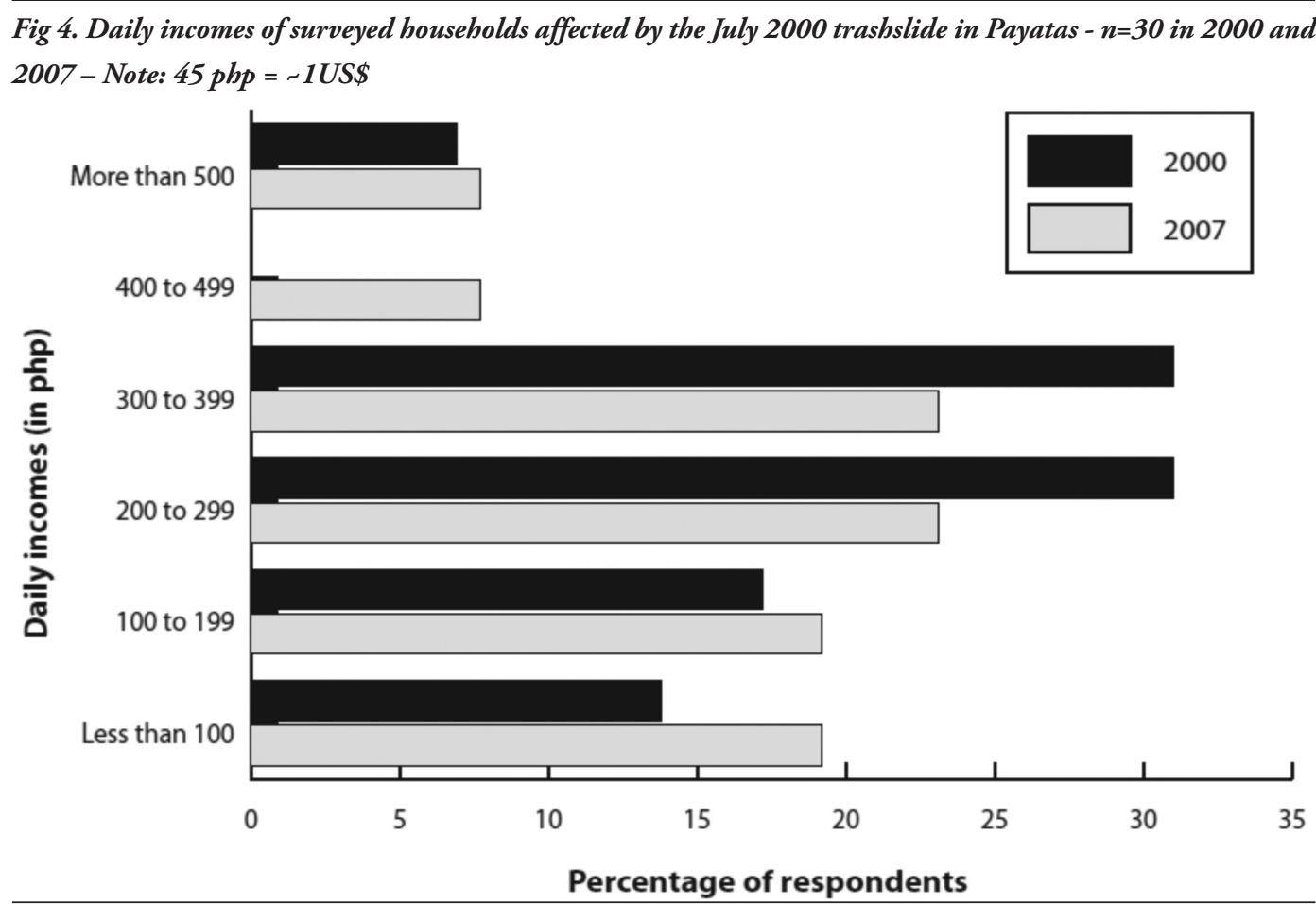

Before the disaster, almost $60 \%$ of the interviewees earned between 5 and 10 US\$ per day. Today, 45\% earn less than 5 US\$ and only 38\% between 5 and 10 US\$ daily. Overall, 63\% of the victims consider that their standard of living has degraded in the aftermath of the July 2000 tragedy.

To cope with the reduction in daily incomes, the victims of the July 2000 tragedy have extensively relied upon social networks. Social networks include four realms. The first, inner realm covers the nuclear family. In the aftermath of the disaster, children often engaged in incomeearning activities. In 2007, 33\% of the interviewees' children were contributing to the household livelihood against only $13 \%$ in 2000 . The second realm includes the larger circle of relatives. Those provide moral support for $35 \%$ of the interviewees and financial assistance for $21 \%$ of them. The third realm is composed of friends and neighbours who similarly give moral (21\% of interviewees) and financial (14\%) aid in time of difficulties. The fourth and outer realm includes acquaintances who usually are informal money lenders on whom the victims increasingly rely for small, high-interest loans (39\% of interviewees). All these social networks were operative before the disaster but to a smaller extent. In the aftermath of the July 2000 tragedy they turned out to be crucial in helping the victims to recover.

Despite the importance of social networks, the sharp decrease in everyday incomes has had a serious impact on people's diet. Altogether $56 \%$ of the interviewees observed a degradation of their daily food intake. To accompany their plate of rice, most of the victims today resort to the cheapest available dishes: vegetables, eggs, dried fishes. Fresh fish and meat have become luxuries. At the same time some families have reduced the quantity of food for each meal. Others rely on cheaper cooked dishes instead of cooking for themselves. As a consequence, local health 
workers interviewed as part of this study observed that, in $2007,10 \%$ of the children below 4 years old were underweight.

On the other hand, most of the interviewees noticed an improvement in terms of access to public services. This is particularly true regarding access to drinking water. Before the tragedy, most of the victims (93\%) relied on deep wells or expensive balloon delivery. Today, $90 \%$ of them have access to the official water network. Access to health care also improved with the recent construction of a new health centre in Lupang Pangako and the continuous service of foreign NGOs. According to local health workers, the easier access to health care and the sanitary conditions within the perimeter of the dumpsite are responsible for the improvement in the health status of children although official data show that tuberculosis is spreading among adults. When questioned on the topic, $50 \%$ of the victims actually consider that their health condition has worsened with frequent coughs, skin diseases, asthma, etc. Finally, $60 \%$ of the victims acknowledge that access to education has improved with new and better facilities in the vicinity, and a large number of scholarships offered by present President Macapagal in 2001 (e.g. Department of Social Welfare and Development, 2007).

\section{Struggling with a new environment: The fate of the resettlers}

The families affected by the July 2000 tragedy who were relocated to the Kasiglahan resettlement site had to face a new environment. They had to adjust to their new house, pay for new expenses, find a new job and discover new neighbours. Before the disaster, most of the relocatees $(56 \%)$ were living in makeshift houses. In Kasiglahan, they received sturdy cemented houses with electricity. Yet almost $13 \%$ of the interviewees have not been able to pay their monthly electricity bill and have been disconnected. Furthermore, they had to wait for a few years before being connected to the water network. In the meantime, they had to rely on deep wells, water delivery or support from NGOs or local organizations. The situation is worsened by the obligation to pay for obtaining the title to their house and lot as their new status of legal settler forces them to do.

The constraint to pay for amenities, house and lot is particularly difficult given the harsh economic environment. Before the July 2000 tragedy, 66\% of the relocatees were scavengers on the Payatas dumpsite. Once relocated to Kasiglahan, they had three choices in order to survive: $1 /$ to go back daily to Lupang Pangako and continue scavenging on the Payatas dumpsite; 2 / to collect and sort garbage on the nearby San Isidro dumpsite; $3 /$ to find a new job. Some 50\% of the relocatees decided to make a living from scavenging in San Isidro. Yet this dumpsite seems to be tightly controlled: scavengers have to follow working shifts of eight hours and children cannot enter the perimeter of the facilities. Moreover, Payatas victims have to pay for transport to San Isidro which is a few kilometres away from the resettlement site. Garbage is also said to be less in quantity than at Payatas. At the same time most of those who chose to look for a new job did not emerge from the informal sector and ended up as street vendors or construction workers.

As a consequence of the increase in expenses and reduction in incomes, $72 \%$ of the victims relocated to Kasiglahan consider that their standard of living has sharply decreased since 2000. 
In fact, almost $40 \%$ of the interviewees earn less than 2.5 US\$ per day, and $70 \%$ less than 5 US\$ (Figure 5), confirming early data gathered by Campomanes et al. (2002).

Fig 5. Daily incomes of surveyed households affected by the July 2000 trashslide in Kasiglahan - $n=30$ - in 2000 and $2007-$ Note: 45 php $=-1$ US\$

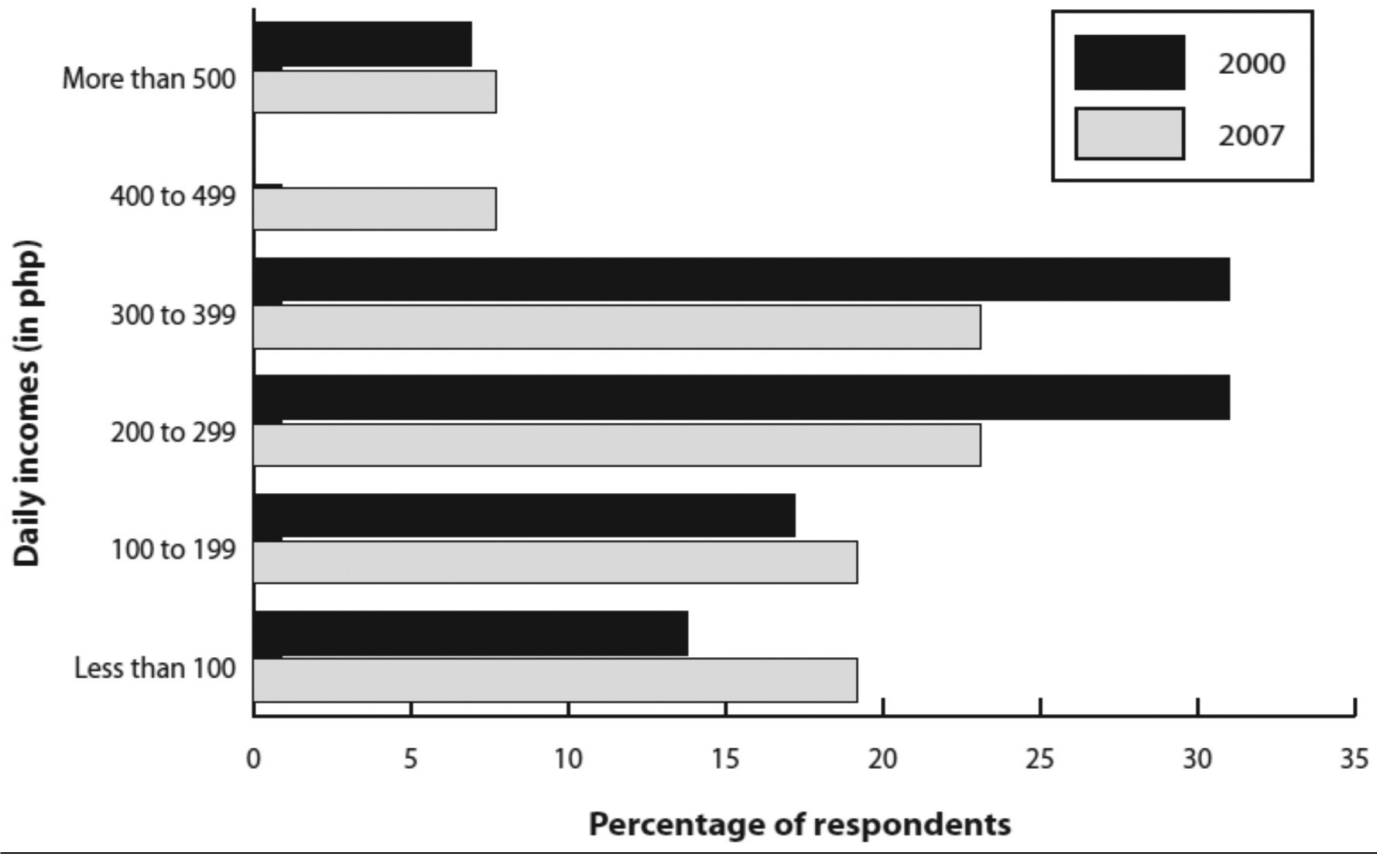

To sustain their daily needs, $64 \%$ of the families resort to small and informal loans from money lenders, neighbours or relatives. As in Payatas, social networks have been very important in helping the victims recover from the disaster. Relatives are the most often approached before friends and neighbours. It should be noted that in Kasiglahan the very active July 10 Payatas Victims Organization (Campomanes et al., 2002) plays a significant role in fighting for the rights of the victims to obtain financial compensation, free education, security of land tenure and livelihood opportunities. The Organization has filed one criminal case and two administrative cases with the Office of the Ombudsman against local officials allegedly responsible for the disaster. As of December 2008, however, none of these cases has been resolved.

The victims' daily diet suffers from their poor incomes. Most of the families often skip a meal a day. Some reduce the quantity of their food intake or rely on the cheapest food available (egg, vegetable, dried fish, tofu). As in Payatas, fish and meat are rare pleasures kept for special occasions.

Another consequence of the relocation to Kasiglahan is the poorer access to health care. Altogether $22 \%$ of the families declare that they have no access to health centres. NGOs also do not maintain a permanent clinic as they do in Payatas. In Kasiglahan, only one nurse has to cater for more than 7,000 families. Yet health problems do not seem to spread because of the cleaner environment compared with Lupang Pangako. Some 52\% of the interviewees further consider that access to educational facilities has remained stable. A significant number of victims 
have indeed benefited from governmental scholarships which have helped children in finishing their primary and secondary education.

Poverty and poor access to livelihoods in Kasiglahan have led $47 \%$ of the relocatees to think that going back to Payatas would be a viable alternative to their miserable life in the resettlement site. Yet $9 \%$ acknowledge that it would depend on their ability to secure a house and lot in Lupang Pangako. A small set of interviews conducted with some of the relocatees who decided to leave Kasiglahan confirmed the crucial role of livelihoods in their choice to settle back in Payatas. Most consider that it is much easier to secure enough income to cover the needs of their family in Lupang Pangako despite makeshift houses and poor sanitary conditions. Indeed, those who went back joined the latest migrants and settled within the danger zone, at the immediate bottom of the dumpsite.

\section{Marginality and the reconstruction of people's livelihoods}

The ability of the Payatas victims to recover in the aftermath of the disaster was closely dependent on the level of marginality they had experienced before the trashslide as reflected by the nature, strength, diversity and sustainability of their livelihoods. The victims who lived in the immediate vicinity of the dumpsite with marginal livelihoods were those who were relocated and had the greatest difficulty in recovering based on the foregoing results of the survey conducted in Kasiglahan. On the other hand, the people of Lupang Pangako who were less marginalized and lived further away from the dumpsite with stronger, more diverse and more sustainable livelihoods proved to be better capable of recovering from the havoc brought about by the disaster.

The capacity of the victims to recover was first dependent on the nature and diversity of their pre-disaster livelihoods. Families who had the hardest time in recovering from the havoc wrought by the trashslide were those who relied on the sole collection of garbage to earn a living. When the dumpsite temporarily closed in the immediate aftermath of the disaster, the scavengers were rendered resourceless and had to depend on external aid. It is only when the dumpsite was reopened that they were able to regain access to livelihoods. Yet it seems that a large proportion of the victims (32\%) were relying on two different livelihoods before the disaster. Half of them were scavengers who raised pigs to complement daily incomes from the dumpsite. Others used to work as construction workers, especially during the dry season (December to May). Those multi-livelihood victims turned out to be the most able to recover as other activities allowed them to cope with the closure of the dumpsite.

The strength of livelihoods was another critical factor in recovery among victims of the July 2000 Payatas tragedy. The average pre-disaster daily family income was around 7.5 US\$ and a third of the households relied on less than 4 US\$. In such a situation, all incomes were immediately spent on purchasing foods and sustaining other everyday needs. Savings were impossible and no spare money was available in the aftermath of the trashslide. People's ability to raise enough income to recover from the disaster was also constrained by structural forces beyond the victims' reach such as inflation. Prices of rice and other food products are soaring in the Philippines while wages are growing slowly. Today, the incomes of the families relocated to 
Kasiglahan are further cut down by the additional expenses linked to the compulsory reimbursement for their new homes which has been confirmed by the officers of the NHA interviewed as part of this study. Alternative sources of support such as loaning money further depend on the extent of social networks and the ability to pay back. The victims who possessed the larger solidarity networks were those who had been living in Payatas for a long time. On the other hand, the poorest and late-coming victims who settled at the immediate foot of the dumpsite had weaker social connections and thus had to resort to high-interest loans from professional money lenders.

Sustainability of livelihoods also turned out to be essential to the ability of the victims to overcome the July 2000 Payatas tragedy. Among those who remained in Lupang Pangako, stability in livelihood prevented a sharp decrease in the household's income, thus preventing them from plunging into chronic endebtment. In Kasiglahan, the ability to regain access to livelihoods was difficult, even among families who relied on several sources of income before the tragedy. Relocated families are those who lost at least one relative in the disaster. A smaller number of adult individuals among each household reduced the ability to raise incomes to sustain the needs of families which included a large number of dependent children. The results of our survey show that $100 \%$ of the households who lost one or more members of their families actually earned less than 5 US\$ a day in 2007. The loss of one or more relatives and continuing decreases in available social capital therefore turned out to be a key determinant of people's ability to recover from the disaster. Furthermore, Kasiglahan is far away from the economic centre of the municipality of Rodriguez and from the San Isidro dumpsite. Maintaining urban livelihoods similar to Payatas forced the victims to pay for expensive transport.

This study of Payatas actually emphasizes that assets and capital essential to the sustainability of livelihoods were crucial in defining people's capacity to recover from the disaster; they were further strongly dependant on the pre-disaster setting materialized by the level of marginality and vulnerability (Figure 6). People's ability to live in hazard-safe places, or far from the dumpsite in the case of Payatas, depended on access to land (natural capital). Skills and knowledge (human capital) enabled the diversification of activities and thus lessened households' dependence on scavenging trash in time of bad weather when trashslides are threatening or when the dumpsite is closed. Income and savings (financial capital) are obviously important for purchasing food in time of scarcity but also for building resistant houses. Social networks and kinship (social capital) were critical in providing alternative support in the wake of the disaster. Finally, the ability to secure access to physical capital (housing, electricity, water networks and transportation) at affordable cost was also important in shaping resettlers' decision to settle back in Payatas and was closely dependent on access to political capital. People's vulnerability in facing trashslide hazards and their ability to recover from the disaster can therefore not be dissociated from livelihood sustainability and marginality. On the other hand, livelihood sustainability is similarly tied to people's vulnerability to hazardous phenomena and disasters as the Payatas trashlide and subsequent relocation ruined resettlers' access to livelihoods and thus reinforced their position at the margin of the society. 


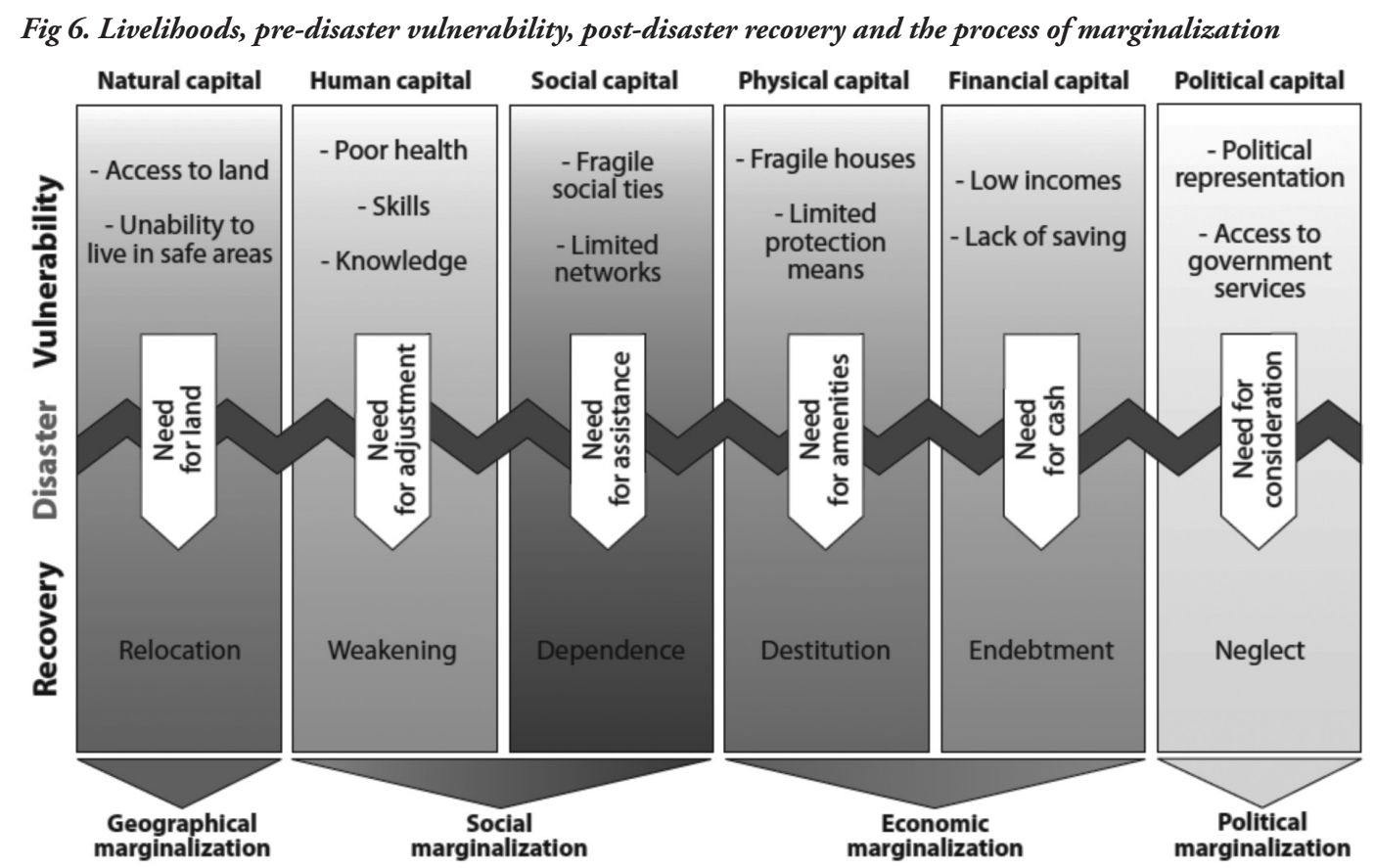

\section{From marginality to further marginalization}

This study of the fate of the victims of the July 2000 Payatas trashslide is a story of marginality and marginalization. Families who were relocated to Kasiglahan were the poorest based on their daily incomes before the disaster (Figure 4 and 5). Relocated households were also the hardest hit by the trashslide because they were living in the immediate vicinity of the dumpsite. They were living there because their limited incomes did not allow them to afford a safer, distant location for their homes. Moreover, they were those among the victims who were the most dependent on scavenging garbage for sustaining their daily needs.

In the present case, the most vulnerable families in the face of the trashslide were eventually those who had to suffer again from life-disrupting relocation while being the less able to recover quickly from the disaster. Yet it is widely acknowledged (e.g. Davis, 1978; Oliver-Smith, 1991; Quarantelli, 1984) that post-disaster resettlement through geographical relocation is among the worst alternatives to spur people's recovery as illustrated in the case of Payatas where daily incomes of families resettled in Kasiglahan are today much lower than those who stayed in Lupang Pangako (Figure 4 and 5). Resettlement is a very complex process that goes beyond the mere rehousing of the victims. It implies the social reconstruction of homes, social and political ties and livelihoods (e.g. Aysan \& Oliver, 1987; Cernea, 1997). These ties are rooted in long cultural, social, economic and political histories (e.g. Scudder \& Colson, 1982; Quarantelli, 1984; Aysan \& Oliver, 1987) and are often constrained by structural forces (e.g. Wisner et al., 2004). In the case of the Kasiglahan relocation site, the Philippine authorities largely focused on the housing dimension of resettlement at the expense of people's livelihoods. Re-establishing such a community-place relationship in a new environment further requires a 
long period of time which is often incompatible with the wish of the disaster victims to settle back as quickly as possible (e.g. Davis, 1978; Scudder \& Colson, 1982; Bernardo, 2004). For these reasons, resettlement often fails to foster sustainable post-disaster recovery (Oliver-Smith, 1991).

The failure of the relocation and overall recovery processes further reflects how marginalized were the victims of the Payatas trashslide on the political scene before the disaster. Most of the affected victims were illegal settlers and thus lacked political visibility. Interviews show that local authorities struggled even to assess their exact number. The official death toll is thus challenged by the representatives of the associations of victims who claim that the trashslide may have killed a thousand people. Local authorities eventually felt that providing squatter victims with permanent and formal resettlement was a favour. It therefore does not come as a surprise that none of the people interviewed as part of this study had been involved in the decision making process which led to their resettlement in Kasiglahan. It is widely acknowledged that the participation of the victims in the planning of the resettlement is a prerequisite to sustainable post-disaster recovery (Davis, 1978; Scudder \& Colson, 1982; Oliver-Smith, 1991). The Payatas resettlement program was top-down in nature and few decision-making opportunities were available to the victims (Campomanes et al., 2002; Bernardo, 2004). In Kasiglahan, the relocatees were not involved in the choice and layout of the site and in the design of the houses. They were forced to accept the program planned by the NHA. Disaster victims are, however, capable of much more than usually expected in time of disaster (Quarantelli \& Dynes, 1972; Davis, 1978). They are neither passive nor traumatized for a long period but willing to settle back as quickly as possible. In the case of the July 2000 Payatas tragedy, the intrinsic will and capacity of the victims to cope and recover from the havoc brought by the disaster have been overlooked by the Philippine government, thus preventing fast recovery. Considering the lingering threat in Payatas, relocation may have been a solution, but only should the victims be strongly involved in the design of the resettlement programme and high emphasis be given to livelihood-related issues.

Political marginalization before and after the disaster inevitably led to social and economic marginalization during the recovery process. The victims of the Payatas trashslide who remained in Lupang Pangako benefited from much more sustainable rehabilitation and reconstruction measures as illustrated by the new school buildings and health centre, and the permanent presence of NGOs. On the other hand, people in Kasiglahan have been the focus of useful, but short-term and limited social and economic support such as educational scholarships which were also provided in Lupang Pangako. As mentioned above, local authorities focused on housing. Providing the resettlers with economic and social assistance ranked lower among the government's priorities. As a consequence, daily incomes of families resettled in Kasiglahan are today much lower than those who stayed in Lupang Pangako and access to services is much poorer. Yet it is today widely acknowledged that ensuring access to sustainable livelihoods is essential to fast post-disaster recovery (Anderson \& Woodrow, 1989; Coate et al., 2006; Pomeroy et al., 2006; Régnier et al., 2008). 
This study emphasizes that it is essential to consider post-disaster recovery in the context of pre-disaster vulnerability. Victims' suffering in the aftermath of the July 2000 Payatas trashslide reflects people's daily needs and chronic marginalization at the dawn of the disaster (Figure 6). Relocation in Kasiglahan resulted from poor access to land before the event. Limited skills and frail health led to an increased fragility in the resettlement site where employment turns out to be limited and access to health care difficult. Limited social, physical and financial capital before the disaster forced the victims to rely on professional money lenders or to sell the few assets they possessed to sustain their daily needs, thus increasing people's dependence on external resources and endebtment. Obviously, the July 2000 trashslide did not bring new issues but increased pre-disaster needs. In that sense, disasters should be considered as the extension of daily hardship intimately linked to pre-disaster marginalization. For the victims of the July 2000 Payatas tragedy, political neglect and poverty thus acted as a vicious, worsening circle which ranged from vulnerability to poor recovery or from marginality to further marginalization.

\section{References}

ANDERSON, M.B. and WOODROW, P. 1989. Rising from the ashes: development strategies in times of disasters. Boulder: Westview Press.

AYSAN, Y. and OLIVER, P. 1987. Housing and culture after earthquakes. Oxford: Oxford Polytechnic Press.

BERNARDO, J.Y. 2004. Payatas: sense of place in contested place. MA Thesis, Department of Anthropology, University of the Philippines Diliman, Quezon City.

BLAIKIE, P. and BROOKFIELD, H. 1986. Land degradation and society. London: Methuan.

BLAIKIE, P., CANNON, T., DAVIS, I., and WISNER, B., 1994. At risk: natural hazards, people’s vulnerability, and disasters. 1st ed. Routledge, London.

CAMPOMANES, J., SANGALANG, C. and UGABAN, R. 2002. KV1: Pakikipamuhay sa Kasiglahan Village I - San Jose Plains, Rodriguez, Rizal. Quezon City: College of Social Work and Community Development, University of the Philippines Diliman.

CANNON, T. 1994. Vulnerability analysis and the explanation of 'natural' disasters. (In: Varley, A., ed. Disasters, development and environment. Chichester: J. Wiley \& Sons, p.13-30.)

CERNEA, M. 1997. The risks and reconstruction model for resettling displaced population. World Development, 25(10):1569-1587.

CHAMBERS, R. and CONWAY, G.R. 1991. Sustainable rural livelihoods: Practical concepts for the $21^{\text {st }}$ century. IDS discussion paper 296. Brighton: Institute of Development Studies.

COATE, B., HANDMER, J. and CHOONG, W. 2006. Taking care of people and communities: rebuilding livelihoods through NGOs and the informal economy in Southern Thailand. Disaster Prevention and Management, 15(1):135-145. 
From marginality to further marginalization: Experiences from the victims of the July 2000 Payatas...

CUNY, F.C. 1983. Disasters and development. New York: Oxford University Press.

DAVIS, I. 1978. Shelter after disaster. Oxford: Oxford Polytechnic Press.

DAVIS, I. 1987. Safe shelter within unsafe cities. Open House International, 12(3):5-15.

DEPARTMENT OF INTERNATIONAL DEVELOPMENT. 1999. Sustainable livelihoods guidance sheets. London: Department of International Development.

DEPARTMENT OF SOCIAL WELFARE AND DEVELOPMENT. 2007. The PGMA scholars: seven years after the Payatas tragedy. Quezon City: Department of Social Welfare and Development.

GAILLARD, J.-C., LE MASSON, V. and CADAG, J.R.D. 2008. Linking post-disaster resilience and access to livelihoods: some preliminary insights from the communities affected by the July 2000 Payatas trashslide in the Philippines. 8th International Conference on Philippine Studies, 23-26 July 2008, Quezon City, Philippines.

KENT, G. 1988. Nutrition education as an instrument of empowerment. Journal of Nutrition Education, 20(4):193-195.

LE MASSON, V. 2008. Lier la résilience post-catastrophe et l'accès aux revenus quotidiens: aperçu des communautés victimes de l'effondrement de la décharge de Payatas en juillet aux Philippines. Ms Thesis, Université de Grenoble, France.

MERRY, S.M., KAVAZANJIAN Jr., E. and FRITZ, W.U. 2005. Reconnaissance of the July 10, 2000, Payatas landfill failure. Journal of Performance of Constructed Facilities, 19(2):100-107.

MIDDLETON, N. and O'KEEFE, P. 1998. Disaster and development: The politics of humanitarian aid. London: Pluto Press.

NATIONAL STATISTICS OFFICE. 2009. 2000 census of population and housing. Manila: National Statistics Office. http://www.census.gov.ph Date of access 5 Oct. 2009

OLIVER-SMITH, A. 1991. Successes and failures in post-disaster resettlement. Disasters, 15(1):12-23.

PECSON, E.C. 2000. Sworn statement at the Office of the Ombudsman - 17 July 2000. Quezon City: Office of the Ombudsman.

POMEROY, R.S., BLAKE, D.R., HALL, S.J., PIMOLJINDA, J.and VIVEKANANDAN, V. 2006. Coping with disaster: rehabilitating coastal livelihoods and communities. Marine Policy, 30, pp.786-793.

QUARANTELLI, E.L. 1984. Social problems of adjustment and relocation: Some questions and some comments. (In Proceedings of the International Conference on Disaster Mitigation Program Implementation. Ocho Rios, Jamaica, 12-16 November 1984, p.84-90.)

QUARANTELLI, E.L. and DYNES, R.R. 1972. When disaster strikes: It isn't much like what you've heard and read about. Psychology Today, 5(9):66-70.

RÉGNIER, P., NERI, B. SCITERI, S. and MIMIATI, S. 2008. From emergency relief to livelihood recovery: Lessons learned from post-tsunami experiences in Indonesia and India. Disaster Prevention and Management, 17(3):410-429

SCUDDER, T. and COLSON, E. 1982. From welfare to development: A conceptual frame work for the analysis of dislocated people. (In Hansen, E. and Oliver-Smith, A. eds. Involuntary migration and resettlement: the problems and responses of dislocated people. Boulder: Westview Press, p.267-287.) 
SEN, A. 1981a. Poverty and famines: An essay on entitlement and deprivation. Oxford: Oxford University Press.

SEN, A. 1981b. Ingredients of famine analysis: Availability and entitlement. The Quarterly Journal of Economics, 96(3):433-464.

START, D. and JOHNSON, C. 2004. Livelihood options? The political economy of access, opportunity and diversification. Overseas Development Institute working paper 233. London: Overseas Development Institute.

SUSMAN, P., O'KEEFE, P. and WISNER, B. 1983. Global disasters, a radical interpretation. (In K. HEWITT, ed. Interpretations of calamity. London: Allen \& Unwin, p.263-283.)

WALKER, P. 1989. Famine early warning systems: victims and destruction. London: Earthscan.

WATTS, M.J. and BOHLE, H.G. 1993. The space of vulnerability: The causal structure of hunger and famine. Progress in Human Geography, 17(1):43-67

WINCHESTER, P. 1992. Power, choice and vulnerability: A case study in disaster mismanagement in South India, 1977-1988. London: James and James Science Publishers.

WISNER, B. 1993. Disaster vulnerability: Scale, power, and daily life. Geojour nal, 30(2):127-140.

WISNER, B. 2009. Bowling alone? Bunding alone? Long-term impact of disasters on social capital. Lecture given at the World Bank in January 2009, Washington D.C.: World Bank.

WISNER, B., BLAIKIE, P., CANNON, T. and DAVIS, I. 2004. At risk: Natural hazards, people's vulnerability, and disasters. London: Routledge. 